\title{
Quantitative aspects of cold-adaptation and its thyroxine model in cold- and warm-blooded animals
}

\author{
Alfred Locker and Peter Weish \\ Institut für Strablenschutz, Reaktorzentrum, Seibersdorf-Wien \\ (Österreichische Studiengesellschaft für Atomenergie G.m.b.H.) \\ und \\ Physiologisches Institut der Universität, Wien, Österreich
}

\begin{abstract}
KURZFASSUNG: Quantitative Aspekte der Kälteadaptation und ihres Thyroxin-Modells bei kalt- und warmblütigen Tieren. Zwischen der Gewebsatmung von Gehirn, Leber und Herz "unadaptierter" Kalt- und Warmblüter (Fröschen und Mäusen) können mit Hilfe der Wirkung von 4,6-Dinitro-o-kresol bei verschiedenen Temperaturen charakteristische Unterschiede aufgedeckt werden, die nach Kälteadaptation ( $4^{\circ} \mathrm{C}$, konstante Beleuchtung) von 1 bis 3 Monaten Dauer verschwinden. Bei Mäusen nimmt unter dem kontinuierlichen Einfluß von Kälte der Gesamtstoffwechsel und die Gewrebsatmung zu, während bei Fröschen dies nur bei Wintertieren geschieht und Sommertiere einen Abfall ihres Stoffwechsels erfahren. Ahnliche Resultate werden bei Fröschen und Mäusen durch chronische Behandlung mit Thyroxin (5 Tage, täglich $6,12 \mathrm{mg} / \mathrm{kg}$ ) erzielt. Trotz der zur Anwendung gekommenen höheren Dosen kann daher Thyroxin die Kältewirkung auf den Stoff wechsel simulieren und die Thyroxinwirkung läßt sich demnach als Modell der Kälteadaptation ansprechen.
\end{abstract}

\section{INTRODUCTION}

Between several tissues of unadapted cold- and warm-blooded animals e. g. frogs and mice exist certain metabolic differences (Locker 1962, 1964). These can be disclosed by the action of a substance stimulating metabolism, namely 4.6-dinitro-o-cresol (DNOC). Under the influence of DNOC the percentage $\mathrm{O}_{2}$-consumption of brain, liver and heart in winter-frogs increases progressively with increasing temperatures in vitro, whereas in the remaining frog tissues and in all tissues of mice, a decrease in the percentage increment of $\mathrm{O}_{2}$-uptake occurs (LOckER 1962). The question now arises whether a chronic stimulus, like exposure to cold, intensifies these metabolic differences between poikilothermic and homoiothermic animals or whether it alters them in a somewhat characteristic way. Since the adaptive changes of metabolism due to cold are connected with an activated thyroid gland, the problem gains interest whether chronic treatment with thyroxine exerts similar or even identical metabolic effects. The search for such effects has been performed on the whole animal metabolism and the respiration of all relevant tissues as well, together with the recording of changes 
in their masses with special consideration of those tissues that play a role in thermogenesis.

\section{MATERIAL AND METHODS}

With adult frogs Rana esculenta females two seasonal forms have been distinguished: summer-frogs (SF) and winter-frogs (WF); the male adult albino mice originated from our own laboratory stock. The "unadapted" animals $(U)$ (also termed "control animals") have been held under normal conditions, i. e. WF's in a cold room, the temperature of which was not constant, SF's and mice at room temperature. The animals exposed to cold $(A)$ spent one to three months in an aerated, permanently lightened thermostat of a constant temperature of $4^{\circ} \mathrm{C}$. A third group of animals $(T)$ received a daily injection of $D, L$-thyroxine $(6.12 \mathrm{mg} / \mathrm{kg}$ body weight $)$ intraperitoneally or into the dorsal lymph sac. During the course of investigation all frogs remained unfed. The other technical details - measuring whole-body $\mathrm{O}_{2}$-uptake with the "constant flow closed circuit system" (after RobBIE) and of tissues in the Warburgapparatus - have been described more extensively elsewhere (LOCKER \& WeISH 1964a, b, WEISH 1965). The tissues whose metabolism or mass have been determined were the following: brain, liver, muscle (gastrocnemius in frogs, diaphragm in mice), spleen, heart, kidneys, intestines and skin (only in frogs).

\section{RESULTS}

\section{Whole animal metabolism}

Figures 1 and 2 demonstrate the $\mathrm{O}_{2}$-uptake of intact animals at different temperatures (the average values and standard deviations have been omitted for clearness reasons; full results in WEISH 1965).

In WF's (Fig. 1a) cold exposure induces an increase of $\mathrm{O}_{2}$-consumption at all ambient temperatures, which is especially significant at lower temperatures; thyroxine increases the $\mathrm{O}_{2}$-consumption even stronger. For the temperature-range between $12.5^{\circ}$ and $35^{\circ} \mathrm{C}$ the activation energy $(\mu)$ amounts to $11,890 \mathrm{cal}$ in unadapted WF's, to $8,865 \mathrm{cal}$ in adapted animals and to $8,718 \mathrm{cal}$ following thy roxine treatment of 5 days.

The unadapted SF's (Fig. 1b) reveal a significantly higher Oq-uptake than WF's (with an increase of more than $100 \%$, especially at lower temperatures). Cold exposure as well as thyroxine treatment bring about a pronounced decrease to a level which is only insignificantly distinguishable from that of cold adapted WF's. The activation energies amount to $9,440 \mathrm{cal}$ in $U$, to $10,180 \mathrm{cal}$ in $A$ and to $7,295 \mathrm{cal}$ in $T$.

The relationship metabolism-temperature of unadapted mice (Fig. 2) obeys in the temperature-range from $12.5^{0}$ to $32.5^{\circ} \mathrm{C}$ the straight line: $\mathrm{Y}=5.61-0.162 \mathrm{X}$ (with highly significant correlation coefficient); between $4^{0}$ and $8^{\circ} \mathrm{C}$ a transition into a plateau ("thermal limit") is indicated. The minimum of metabolism ("zone of thermoneutrality", TNZ) is located at $35^{\circ} \mathrm{C}$. In both cases of cold exposure and thyroxinetreatment, the $\mathrm{O}_{2}$-uptake is increased; the TNZ becomes narrower and the metabolic 

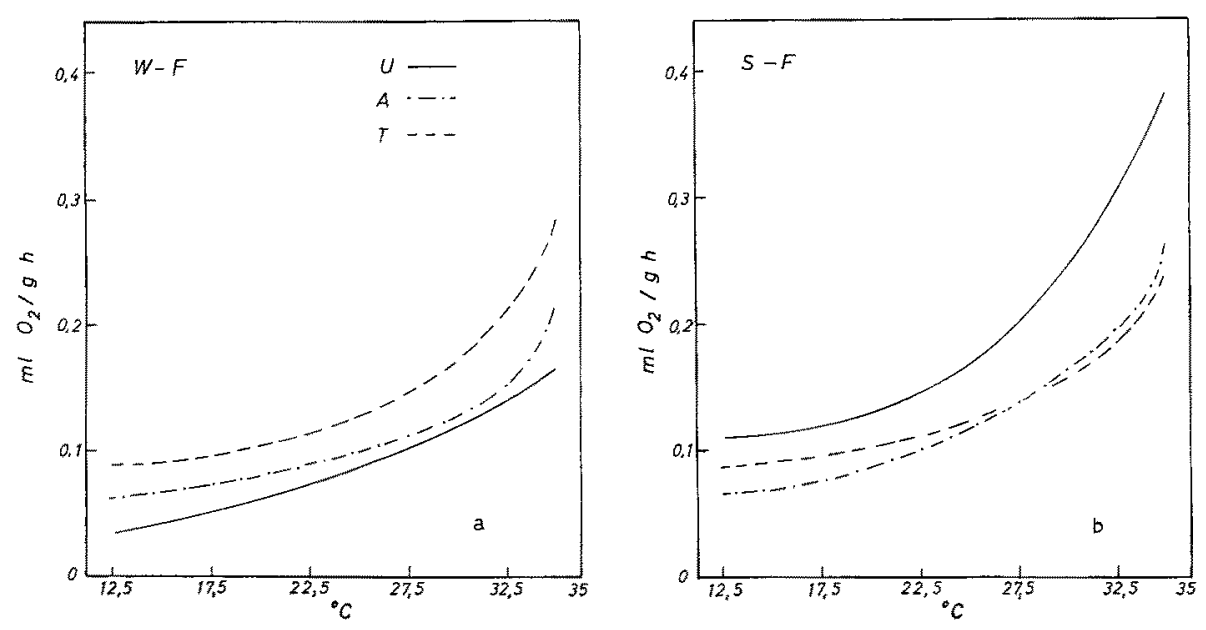

Fig. 1: Oz-consumption (ordinate) of intact adult winterfrogs (WF) (1a) and summer frogs (SF) (1b) within the range of temperature between $12.5^{\circ}$ and $35^{\circ} \mathrm{C}$ (abszissa). Curves have been smoothed to the average values. $U$ : unadapted animals; $A$ : cold exposed adapted animals; $T$ : thyroxine treated animals

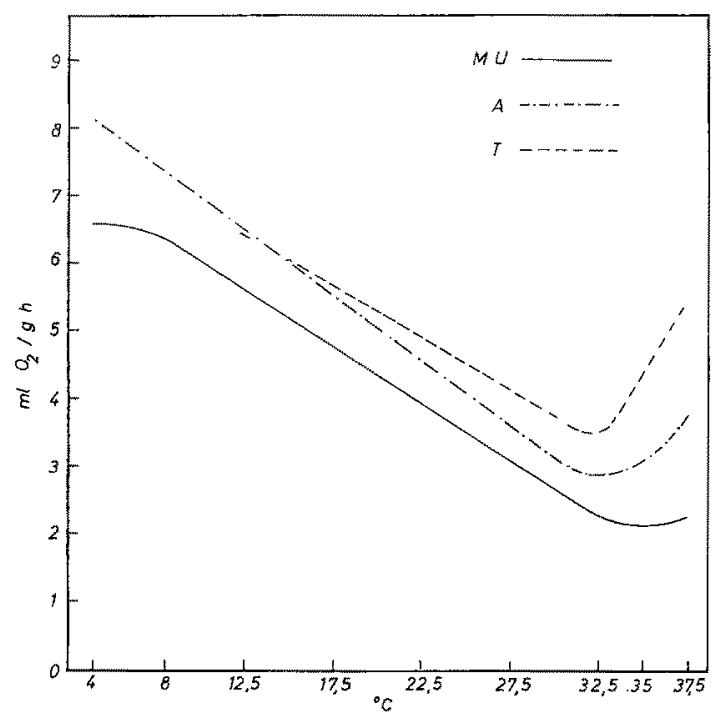

Fig. 2: $\mathrm{O}_{2}$-consumption (ordinate) of adult albino mice within the temperature range (abszissa) from $4^{0}$ (or $12.5^{\circ}$ ) to $37.5^{\circ} \mathrm{C}$. Between 12.5 and $32.5^{\circ}$ computed regression lines; other parts of the curves smoothed to the average values; $U, A$ and $T$ : denotations as in Figure 1

minimum is displaced to $32.5^{\circ} \mathrm{C}$. Within the range of $12.5^{\circ}$ to $37.5^{\circ} \mathrm{C}$ Og-uptake of the cold adapted mouse corresponds to the straight line: $\mathrm{Y}=6.56-0.194 \mathrm{X}$ (with a highly significant correlation coefficient); after thyroxine treatment the line obeys the relation $\mathrm{Y}=6.40-0.134 \mathrm{X}$ (also with a highly significant correlation coefficient). 
Between unadapted and cold-adapted animals exists a highly significant difference in the slope of the lines. Despite some quantitative differences between the curves of coldadapted and thyroxine-treated cold- and warm-blooded animals, the deviations from the controls are essentially the same, and therefore a striking similarity between cold adaptation and chronic thyroxine application can be perceived.

\section{Tissue respiration}

\section{Uninfluenced tissue respiration}

In WF's cold adaptation induces a partly significant increase in tissue respiration of brain, muscle, heart and kidneys; thyroxine has a similar effect. The tissue respiration of unadapted SF's is essentially higher than that of WF's. Considered as a percentage average of all temperatures studied, the increase amounts to $50 \%$ in heart and liver, to $40 \%$ in brain and muscle and to $20 \%$ approximately in kidneys, skin and intestines. Cold exposure as well as thyroxine treatment do not profoundly change tissue respiration except for that of the heart, where thyroxine brings about a $40 \%$ increase. This means that in SF's after cold exposure lasting until 3 months practically no capacity adaptation of tissues can be observed. In the majority of the tissues of mice, namely in brain, muscle, heart and liver, respectively, cold adaptation exerts an increase of $\mathrm{O}_{2}$-uptake of approximately 20 to $25 \%$; spleen and intenstine remain, however, almost unchanged. An essentially stronger increase of tissue respiration can be found as the result of thyroxine treatment, i. e. in the brain an enhancement of approximately $40 \%$, the heart of $55 \%$ and the liver and muscle even of $70 \%$.

\section{Tissue respiration under the influence of DNOC}

The addition of DNOC in vitro $\left(10^{-5} \mathrm{M}\right.$ final -concentration) induces an increase of tissue respiration the percentage of which is dependent on temperature. In the Figures 3 to 5 the DNOC effect is expressed as percentage activity (uninfluenced tissue respiration being $100 \%$ ) for brain, liver and muscle within the range of temperature between 12.5 and $37.5^{\circ} \mathrm{C}$ (from individual registrations regression lines have been computed).

In the brain of unadapted WF's (Fig. 3a) the DNOC effect increases with increasing temperature. Exposure to cold as well as thyroxine treatment produce a significant alteration of this behaviour: in both instances activity decreases now with increasing temperature. A similar result is found in the SF's (Fig. 3b); the DNOC induced respiratory activity seems to remain rather independent of temperature in controls, whereas cold adaptation as well as thyroxine cause a decrease of it with increasing temperatures. This effect is reversed in the mouse brain (Fig. 3c); the rather steep decline of DNOC induced respiratory stimulation in controls becomes flatter after cold adaptation and is markedly depressed by thyroxine treatment. 
In the liver (Fig. $4 a-c$ ) of unadapted WF's and SF's, a raising DNOC increment can be recorded together with increase of temperature. Cold exposure and thyroxine treatment both alter this relation in direction to a decrease of DNOC induced
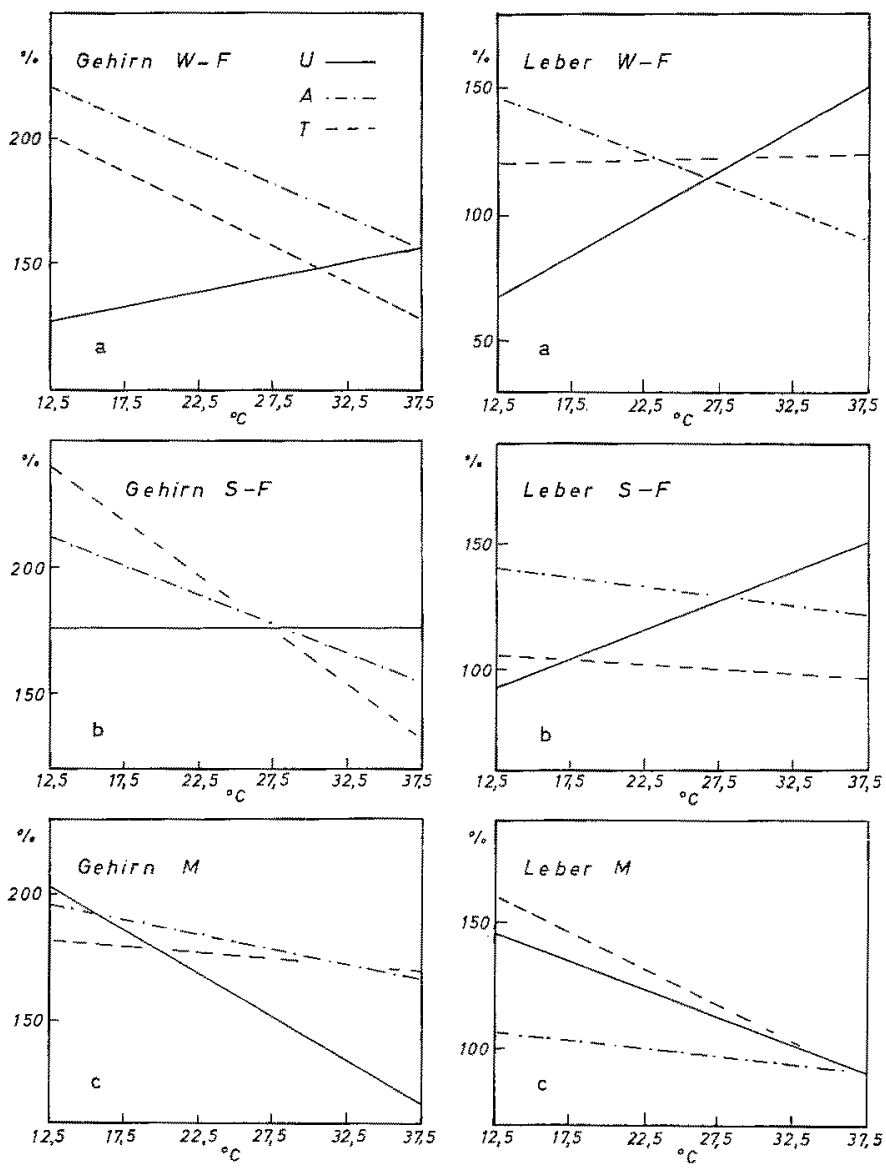

Fig. 3: Percentage tissue respiration (ordinate) as influenced by DNOC of frog's brain at temperatures between 12.5 and $37.5^{\circ} \mathrm{C}$ (abszissa). WF: winter frog, SF: summer frog, $\mathrm{M}$ : mouse. $U, A$, and $\mathrm{T}$ : denotations as in Figure 1. - Fig. 4 (right column): Percentage tissue respiration due to DNOC of liver; ordinate and abszissa (see Fig. 3)

activity at higher temperatures. In the liver of the mouse a decrease of the DNOC activated respiration becomes apparent at lower temperatures, in contrast to thyroxine that has no significant action here.

Following cold exposure or thyroxine treatment the DNOC effect on $\mathrm{m} \mathrm{uscle}$ respiration (Fig, 5a-c) of WF's decreases in the same way. In the SF's, however, whose controls have yet a higher respiration than WF's, no further changes occur under the experimental influences. Also in the mouse muscle cold exposure and thyroxine treat- 
ment are well comparable actions since both influences exert the same quantitative change of respiration over the whole range of temperature.
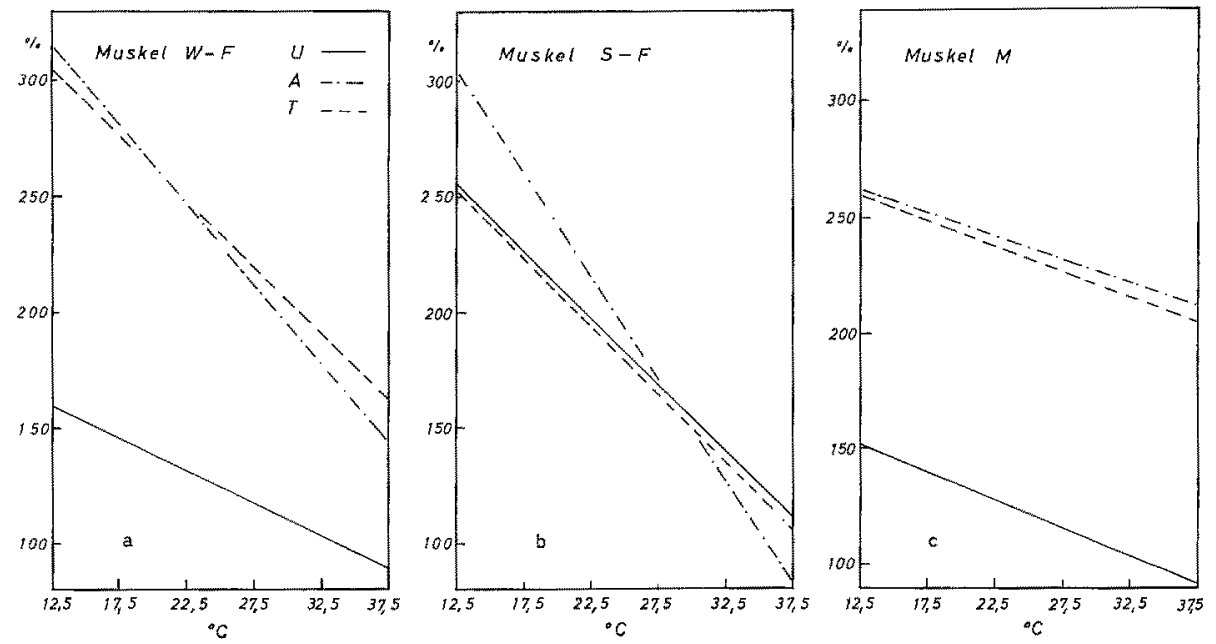

Fig. 5: Percentage tissue respiration under the influence of DNOC of muscle (denotations see Fig. 3)

\section{Organ weights}

Following the 1 to 3 months duration of cold exposure, a small decrease of total fat and muscle mass can be observed in the mouse in comparison with untreated controls. Statistically significant, however, is the pronounced increase of the weight of the interscapular (brown) fat, which reaches a percentage of body weight of 0.67 after cold adaptation, whereas in unadapted mice it amounts only to $0.35 \%$ of body weight. With the organs of WF's (SF's not yet being investigated) no clear-cut differences from the controls can be found. For full details see WEISH (1965); a previous description of the metabolic results was also given by Locker \& WEISH $(1964 a$, b).

\section{DISCUSSION}

The alteration of whole body metabolism following cold exposure in WF's corresponds to adaptation type 3 of PRECHT (1955). However, also under the influence of thyroxine, this type of adaptation appears. The depression of whole body metabolism brought about by cold exposure in SF's could be considered an example of the rare inverse compensation (type 5 of PRECHT). This appears to be a contrast to the results of STANGENBERG (1955), who after cold exposure observed in $R$. esculenta an increase of $\mathrm{O}_{2}$-consumption (measured at $20^{\circ} \mathrm{C}$ ) during the whole year. These different results cannot strictly be compared, however, since (1) the exposure period in the investigation of STANGENBERG (1955) was very short (only 6 to 8 days), (2) the 
adaptation temperature was higher $\left(6^{\circ} \mathrm{C}\right)$ and $(3)$ the animals remained in the dark during cold exposure. Our own somewhat peculiar results probably suggest a reasonable explanation on the basis of the fact that a long lasting cold exposure such as in our investigation interfered with the seasonal (autumnal) decline of metabolism. Nevertheless, this explanation can hardly be applied to the metabolic decrease of the whole body metabolism of SF's following thyroxine, since the treatment covered only a period of several days. The observed decrease indicates that the thyroxine doses applied exceeded by far the physiological range.

In the mouse whole body metabolism increased at every temperature through the influence of both modes of treatment. The more pronounced divergence of metabolism-temperature curves between treated and control animals expresses an improvement in the capability for heat production and a meaningful increase in cold resistance; this is also made obvious by the disappearence of the plateaus ("thermal limits") yet recognizable in the controls. The increase of cold resistance coincides with a diminished heat resistance, as can be judged from the steeper metabolic increase beyond the TNZ. The raise of metabolism brought about by thyroxine is even more pronounced than that in cold adaptation, which can clearly be demonstrated at lower temperatures. Although in the range of "cold-counterregulation" the decrease (or increase) of the straight line differs somewhat between cold exposed and thyroxine treated mice, both processes are, in general, rather similar, the similarity extending also to the shift of the TNZ (from $35^{\circ} \mathrm{C}$ to $32.5^{\circ} \mathrm{C}$ ).

As an effect of cold exposure in all tissues of WF's - except in skin and intestine an increase of $\mathrm{QO}_{2}$ occurs revealing a capacity adaptation which is well simulated by thyroxine treatment. This capacity adaptation, indeed, is absent in SF's. Also in mice the average changes in tissue respiration occurring after thyroxine are well comparable with those brought about by cold exposure. A striking effect is, that the stronger action of thyroxine onto whole body metabolism can be pointed out also at the tissue level. Therefore, it can be assumed that a somewhat lowered dosage of thy roxine would have brought about still a better correspondence between cold adaptation and thyroxine treatment.

In brain and liver, partially also in heart, of SF's and WF's, under the influence of DNOC, a decrease in the percentage stimulation with increasing temperatures occurs, which indicates that the metabolic differences existing in these tissues of unadapted animals disappear as an effect of cold exposure. Also here, thyroxine acts in the same way. In muscle the DNOC stimulated respiration behaves differently between SF and WF. In the WF's following cold or thyroxine treatment, the precentage increase of tissue respiration is consistently the same at all temperatures, whereas in SF's no increase at all can be observed. The absence of capacity adaptation in muscle tissue of SF's is probably the cause for this equal amount of the percentage DNOC enhancement (all 3 groups of investigation).

In SF's at all three groups of investigation $(U, A, T)$ the DNOC enhanced tissue respiration remains practically at the level of the groups $A$ and $T$ of WF's. This result was unexpected if one starts with the assumption that increased muscle respiration is caused by an increase in enzyme activity. In that case the percentage increase in respiration due to DNOC had to be lower than in WF's; and in these animals, in turn, it 
should have been the greatest in the controls. The mouse diaphragm behaves quite similarly, a fact which generally rules out the above mentioned assumption.

A few problems should be discussed in connection with the action of thyroxine. TATA (1964) makes the statement that most investigators work with unphysiologically high, even toxic doses of the hormone; the results of such investigations are therefore of questionable value. This objection is fully justified if the exact action mechanism of hormones should be elucidated. Nevertheless, in our present investigation (having applied higher doses) we may cite several reasons:

(1) We did not use thyreoidectomized animals, and it is well known that euthyroid organisms only react weakly upon low doses of thyroxine. (2) A synthetical thyroxine has been applied, which is a mixture of $\mathrm{D}$ - and L-thyroxine. As a matter of fact the effectiveness of D-thyroxine is less than that of the L-form (Henriques 1964). (3) The relationship between dose and effect, which is valid for rats cannot be uncritically transferred to mice.

Concerning the mechanism of cold-adaptation we may start with several biochemical results, the basis of which may enable us to interpret our present findings. In liver mitochondria of rats a decrease in the efficiency of oxidative phosphorylation could be found as a result of exposure to cold (PANagos, Beyer \& MAsoro 1958, SMITH \& Farrhurst 1958) together with doubling the heat production of this organ. The authors also ascribe to this mechanism of heat production a highly selective inference for the evolution of homoiotherms. However, the primary significance of uncoupling cannot be represented by increased heat production, since similar processes have been found in poikilotherms: KANUNGo \& Prosser (1959) observed a diminished $\mathrm{P} / \mathrm{O}$ ratio in the liver of cold-adapted goldfish. This decrease of $\mathrm{P} / \mathrm{O}$ ratio of liver mitochondria of poikilothermic and homoiothermic animals can be considered an indication for the possibility that the primary mechanism of cold adaptation are in both groups of organism the same. This is in accordance with our result that cold adaptation causes metabolic differences previously revealed between certain tissues of cold- and warm-blooded animals to disappear. One has probably to be cautious in assuming a general validity of these findings. From a recent paper (BALDINI \& MARINARI 1964) it can be seen, that following cold exposure $\left(5^{\circ} \mathrm{C}\right)$ the $\mathrm{P} / \mathrm{O}$ ratio of liver mitochondria of frogs is relatively high; its maximum occurs if temperature of exposure in vivo and temperature of experiment in vitro coincide. $\mathrm{P} / \mathrm{O}$ ratio shifts down abruptly following exposure to heat. It is obvious that methodical conditions are of major importance for differences in results.

The present results with DNOC stimulated tissue respiration are indicative for different mechanisms of cold adaptation in several organs. For instance, in the liver of mouse the decreasing DNOC-increment (with increasing temperatures) could be explained with uncoupling of oxidative phosphorylation, in accordance with the results in rats (PANAgos 1958, SMith \& Fairhurst 1958): on the basis of yet existing uncoupling the effect of an additional uncoupling agent has to become reduced. For the muscle of the mouse the relationships are exactly the opposite, i. e. following cold exposure the DNOC induced respiratory stimulation increases profoundly. This would demonstrate that at least in this tissue the biochemical mechanism of cold adaptation cannot be based upon simple uncoupling. The alterations of activation energies of 
whole body metabolism and of tissue respiration as well have been extensively discussed elsewhere (LOCKER \& WEISH 1964a, b).

\section{SUMMARY}

1. In water frogs (Rana esculenta) and albino mice, as representatives of poikilothermic and homoiothermic animals, the metabolic effects of cold exposure are compared with those occurring after multiple injection of thyroxine. $\mathrm{O}_{2}$-uptake of whole animals and tissue respiration are measured in the temperature range of $4^{0}$ (or $12.5^{\circ}$ ) to $37.5^{\circ} \mathrm{C}$. The latter was also influenced by 4.6 -dinitro-o-cresol (DNOC $\left.10^{-5} \mathrm{M}\right)$. The animals were exposed to cold $\left(4^{\circ} \mathrm{C}\right)$ under constant light for 1 to 3 months. Thyroxine treatment $(6.12 \mathrm{mg} / \mathrm{kg})$ lasted 5 to 6 days; organ masses have been determined too.

2. Cold exposure exerts in winter frogs (WF's) an increase, in summer frogs (SF's) a decrease of whole body metabolism. In mice the whole body metabolism is likewise enhanced by cold exposure, the thermoneutrality zone being displaced toward lower temperature, thus indicating a reduction in heat resistance. The increase of metabolism is to be interpreted as capacity adaptation, the decrease (as it occurs in $\mathrm{SF}^{3}$ s) is probably due to an overlapping of cold exposure with seasonal alterations of metabolism. The thyroxine action is in both instances similar to that of cold exposure.

3. As a further effect of cold adaptation in mice a highly significant weight increase of the (brown) interscapular fat can be recorded.

4. In WF's cold exposure causes a capacity adaptation of the respiration of brain, heart and kidneys (in vitro), whereas in SF's such an adaptation can only be found in the heart.

5. The earlier described differences in the tissue respiration of brain, liver and (partially) heart between unadapted WF's and mice, which could be demonstrated by means of the action of DNOC at different temperatures, can also be found between unadapted SF's and mice. However, cold exposure as well as thyroxine treatment brings about a complete disappearance of these differences.

6. On the basis of the present findings with whole body and tissue metabolism the chronic treatment with thyroxine can be considered as a model of cold adaptation.

\section{LITERATURE CITED}

BALDINI, I. \& MARINARI, U. M., 1964. Influence de température de l'air ambient sur quelques activités métaboliques d'animaux hétérothermes. Experientia 20, 401-402.

Henriques, U., 1964. Effect of some thyroxine analogues on hypothyroid tadpoles. Acta endoc., Copenh. 45, 187-196.

Kanungo, M. S. \& Prosser, C. L., 1959. Physiological and biochemical adaptation of goldfish to cold and warm temperatures. 2. Oxygen consumption and oxidative phosphorylation of liver mitochondria. J. cell. comp. Pbysiol. 54, 265-274. 
Locker, A., 1962. Uber Stoffwechselunterschiede zwischen den Geweben kalt- und warmblïtiger Tiere. (Zugleich ein Beitrag zur Frage: Poikilothermie als Strahlenschutz.) Pfitigers Arch. ges. Physiol. 275, 238-255.

- 1964. Reaktionen metabolisierender Systeme auf experimentelle Beeinflussung, Reiz und Schädigung (Grundprobleme der quantitativen Biologie des Stoffwechsels). Helgoländer wiss. Meevesunters. 9, 38-107.

- \& WEISH, P., 1964a. Stoffwechselunterschiede zwischen Kalt- und Warmblïtern bei der Kälteadaptation. Zool. Anz. (Suppl. Bd) 28, 365-378.

- \& WeISE, P., 1964b. Der Stoffwechsel von Kalt- und Warmblittern unter chronischer Thyroxineinwirkung als einem Modell der Kälteadaptation: TagBer. Gemeins. Tag. Dt. Ges. Biophysik, Österr. Ges. Reine Angew. Biophysik \& Schweiz. Ges. Strahlenbiol., Wien, $1964,19-26$.

Panagos, S., Beyer, R. E. \& Masoro, E. J., 1958. Oxidative phosphorylation in liver mitochondria prepared from cold-exposed rats. Biochim. biophys. Acta 29, 204.

Precht, H. 1955. Wechselwarme Tiere und Pflanzen. In: Precht, H., J. Christophersen \& H. Hensel: Temperatur und Leben. Springer, Berlin, $177 \mathrm{pp}$.

SMITH, R. E. \& EAIRHuRST, A. S., 1958. A mechanism of cellular thermogenesis in cold adaptation. Proc. natn.. Acad. Sci. U.S.A. 44, 705-711.

Stangenberg, G., 1955. Der Temperatureinfluß auf Lebensprozesse und den Cytochrom c-Gehalt beim Wasserfrosch. Pfingers Arch. ges. Pbysiol. 260, 320-332.

TATA, J. R., 1964. Biological action of thyroid hormones at the cellular and molecular levels. In: Actions of hormones on molecular processes. Ed. by G. Litwack \& D. Kritchevsky. Wiley \& Sons, New York, 58-131.

WEISH, P., 1965. Veränderungen des Stoffwechsels homoiothermer und poikilothermer Tiere bei Kälteadaptation und exogener Thyroxinwirkung. Wien, Phil. Diss., $133 \mathrm{~S}$.

\section{Discussion following the paper by LOCKER \& WEISH}

Precht: Was nennen Sie unadaptiert? Haben Sie ein Tier in der Kälte gehalten und ein anderes bei Zimmertemperatur? Oder ist das unadaptierte Tier das Sommertier und das bei Kälte adaptierte Tier das Wintertier? Der Sauerstoffverbrauch von im Dunkeln im Eisschrank gehaltenen Fröschen zeigt in der Laichzeit eine enorme Steigerung; dieser Jahresrhythmus ist völlig unabhängig von der Temperaturadaptation.

LOCKER: Selbstverständlich ist es das adaptierte Tier, das zum Unterschied von dem bei Zimmertemperatur gehaltenen Kontrollitier einer bestimmten konstanten Temperatur ausgesetzt wird. Im strengen Sinn gibt es aber natürlich kein "unadaptiertes" Tier, sondern wir vergleichen stets zwischen $4^{0} \mathrm{C}$ und Zimmertemperatur. $\mathrm{Daß}$ die durch Adaptation bewirkte Stoffwechselsteigerung mit einer saisonbedingten Stoffwechseländerung interferieren kann, ist bekannt und mag vielleicht die Ursache für den scheinbar paradoxen Effekt gewesen sein, daß sich durch Kälteadaptation der hohe Stoff wechsel der Sommertiere verringerte.

DONHOFfER: Es gibt mehrere Analogien zwischen Thyroxin-Behandlung und Kälteexposition, doch läßt sich in manchen Fällen zeigen, daß es sich in Wirklichkeit nur um Simulation und nicht um denselben Vorgang handelt. Zum Beispiel senken Thyroxin und Kälte das Leberglykogen in den ersten Tagen im gleichen Ausmaß, doch steigt es in der Kälte dann wieder an, während es bei Thyroxin auf dem Minimalwert bleibt, unabhängig davon, ob der Versuch bei Zimmertemperatur oder in der Kälte $\left(5^{\circ} \mathrm{C}\right.$ ) vorgenommen wird (vgl. M. Farkas, Acta physiol. bung., im Druck). Können Ratten zwischen einem kohlenhydratreichen, fettreichen oder eiweißreichen Futter frei wählen, so wird in der Kälte und unter Thyroxinwirkung der ganze Mehrbedarf durch das kohlenhydratreiche Futter gedeckt. Der Schluß, daß es sich in beiden Fallen eigentlich um eine Thyroxinwirkung handelt, ist jedoch falsch: thyreoidektomierte Tiere ändern ihre Nahrungswahl in derselben Weise (J. Andik \& Sz. Donkorfer, Pfliigers Arch. ges. Physiol. 264, 585, 1957). 
Locker: Das vielleicht wichtigste Indiz darauf, daß die Thyroxinwirkung die Kältewirkung, wie Sie richtig sagen, nur „simuliert“, ohne mit ihr identisch zu sein, ist ja die Tatsache, daß auch thyreoidektomierte Tiere zur Kälteadaptation gebracht werden können.

Hess: Man muß von der Frage ausgehen, welche Möglichkeiten bestehen, den Stoffwechsel zu beeinflussen. Die Zelle hat zwei Möglichkeiten. Einmal können an vielen Stellen des Stoffwechsels Enzymaktivitäten durch sogenannte Kontrollmetabolite innerhalb von Sekunden bis Millisekunden verstärkt oder gehemmt werden. Stoffwechselprozesse wie Glykolyse oder Atmung sprechen auf derartige Kontrollwirkungen mit Ubergangszeiten von etwa 1 bis $20 \mathrm{sec}$ an. Die Kontrolle der oszillierenden Glykolyse beruht auf diesen Wechselwirkungen. Zweitens kann der Zellstoffwechsel durch Enzyminduktion oder Enzymrepression regulativ beeinflußt werden. Enzymkonzentrationen ändern sich durch verstärkte Eiweißsynthese oder Enzyminaktivierung. Diese Vorgänge benötigen Übergangszeiten von Minuten bis Stunden. Ich habe den Eindruck, daß bei Ihren Versuchen durch Kälteinduktion Enzymkonzentrationen infolge vermehrter Eiweißsynthese verändert werden. Ihre Ergebnisse entsprechen dem Zustand, den LARDY durch Verabfolgung von Schilddrüsenhormon induziert hat. LARDY hat gefunden, daß die Aktivität der $\alpha$-Glycerophosphatoxydase von Rattenleber-Mitochondrien durch Schilddrüsenhormon auf etwa das 50fache induziert wird. Die Folge ist ein vermehrter Sauerstoffverbrauch und eine teilweise entkoppelte Atmung. Da Sie mit dem von Ihnen benutzten Test die Koppelung der Atmung prüfen, finden Sie auch entsprechend den von LARDY beschriebenen Werten eine herabgesetzte Koppelung. Herr V. P. Skulatchev, Direktor des Department of Bioenergetics, State University, Moscow, hat vor einiger Zeit über ähnliche Ergebnisse bei der Untersuchung der Kälteadaptation berichtet.

LOCKER: Die von uns in einigen Geweben durch den DNOC-Test nach Thyroxineinwirkung nachgewiesene Entkopplung dürfte sekundär sein; das Hauptergebnis der Thyroxinbehandlung ist sicher die Stimulation der Eiweiß- und damit Enzymsynthese (TATA, J. R., in: Actions of hormones on molecular processes. Ed. by G. Litwack \& D. Kritchersky; Wiley, London 1964, 58 ff.), um so mehr, als die kalorigene Wirkung des Schilddrüsenhormons erst nach der Steigerung der Proteinsynthese einsetzt. Unsere Untersuchung gibt aber auch einen Hinweis darauf, daß der Stoffwechseleffekt nicht durchgehend mit Entkopplung zu erklären ist, denn diese ist nach unseren Ergebnissen nur in der Leber, nicht aber im Skelettmuskel wahrscheinlich.

SCHARF: Thre Versuche sind nicht leicht zu interpretieren, weil sich vielfältige Effekte überlagern. Einmal spielen sich Vorgänge auf cytoplasmatischem und mitochondrialem Niveau ab, zum anderen solche, die endokrinologisch interpretiert werden müssen. Die ziemlich hohe Thyroxindosis von 6,12 mg. kg-1 Tag $^{-1}$ über eine Woche wirkt sicher nicht mehr allein über den hypophysären Fühler, sondern blockiert bereits unmittelbar den normalen Funktionsablauf der thyreoidalen Fermentkette.

LOCKer: Gewiß sind wir mit unseren Dosen weit über den physiologischen Normalbereich hinausgegangen und dadurch auch allen den kritischen Einwänden ausgesetzt, die TATA (1964) diesbezüglich äußert. Jedoch arbeiteten wir mit euthyroiden Tieren, die auf geringe Thyroxindosen noch nicht ansprechen, ferner mit synthetischem Hormon (Gemisch aus D- und L-Thyroxin), während die eigentliche Wirkform das L-Thyroxin zu sein scheint, weshalb auch hier die Dosen etwas höher zu wählen waren, und außerdem war es nicht a priori wahrscheinlich, daß die Dosis-Wirkungsbeziehungen, die für die Ratte, das hier am besten untersuchte Tier, gelten, ohne weiteres auf Frosch und Maus übertragen werden könnten. 